\title{
Impact of decalcification on antibacterial properties of eggshell against selected poultry pathogens
}

\author{
${ }^{* 1}$ Balogu, T. V., ${ }^{1}$ Chukwueze, B. C., and ${ }^{2}$ Okonkwo, T. P. \\ ${ }^{1}$ Department of Microbiology, Ibrahim Badamasi Babangida University, Lapai, Nigeria \\ ${ }^{2}$ Department of Chemistry, Ibrahim Badamasi Babangida University, Lapai, Nigeria \\ *Correspondence to: tovin2009@yahoo.com
}

\begin{abstract}
:
Background: Eggshell which is primarily composed of more than $98 \%$ calcium carbonate crystal, serves as the physical protective and active barrier structure of egg content. Recently, antimicrobial properties of eggshell are fast becoming center of interest among stakeholders of poultry industry. However, few studies have focused on the rigidity factor of calcium components of eggshell as antimicrobial agent. Thus, this study was designed to determine the effect of decalcification on the ability of eggshell to inhibit common poultry and egg bacterial pathogens.

Methods: Raw eggshell denoted as calcified eggshell (CES) and decalcified eggshell (DES) were extracted and made into fine powder. Standard protocol was used for preparations of CES and DES at concentrations of 10, 5, 2.5 and $1.25 \mathrm{mg} / \mathrm{ml}$, and their antibacterial assays on selected bacterial pathogens (Bacillus subtilis, Klebsiella pneumoniae, Pseudomonas aeruginosa, Escherichia coli and Salmonella Typhi) were performed by agar diffusion method. Gentamicin $80 \mathrm{mg}$ solution (CC1) and distilled water (CC2) served as controls. Data were analysed with SPSS version 20.0 and presented as mean \pm SD for descriptive statistics. Friedman's two-way test ANOVA was used to compare the differences in mean values between CES, DES, CC1 and CC2 at significance level of $p<0.05$.

Results: The mean zone diameter of inhibition produced by DES (range $13-28 \mathrm{~mm}$ ) for the isolates was significantly higher $(p<0.05)$ than that produced by CES (range $10-21 \mathrm{~mm})$. However, the mean zone diameter of inhibition produced by CC1 (gentamicin) (range $16-40 \mathrm{~mm}$ ) was higher than that produced by DES or CES $(p<0.05)$. The concentrations of DES and CES have no significant antibacterial effect on $B$. subtilis and $K$. pneumoniae $(p>0.05)$, but had inverse effect on $P$. aeruginosa. Overall, DES had a better inhibitory effect than CES against $B$. subtilis, $K$. pneumoniae and $P$. aeruginosa, but notably, neither DES nor CES had inhibitory effect on $E$. coli and $S$. Typhi.

Conclusion: Poor antibacterial effect of CES may be attributed to the calcium-protein interactions within bacterial cell membrane, which hinders absorption or mobility mechanism of the antibacterial factor of the eggshell, but decalcification had significant impact on the antibacterial profile of the eggshell for some bacterial isolates. However, $S$. Typhi and E. coli were totally resistant to both DES and CES. Breed of eggs with minimal calcified eggshell to withstand transportation fragility, may enhance antibacterial index and shelf-life of table eggs.
\end{abstract}

Keywords: Decalcification; Antibacterial; Eggshell; Poultry; Pathogens.

Received May 5, 2020; Revised Nov 25, 2020; Accepted Jan 5, 2021

Copyright 2021 AJCEM Open Access. This article is licensed and distributed under the terms of the Creative Commons Attrition 4.0 International License <a rel="license" href="http://creativecommons.org/licenses/by/4.0/", which permits unrestricted use, distribution and reproduction in any medium, provided credit is given to the original author(s) and the source. Editor-in-Chief: Prof. S. S. Taiwo

\section{Impact de la décalcification sur les propriétés antibactériennes de la coquille d'œuf contre certains pathogènes de la volaille}

\author{
${ }^{* 1}$ Balogu, T. V., ${ }^{1}$ Chukwueze, B. C., et ${ }^{2}$ Okonkwo, T. P. \\ ${ }^{1}$ Département de microbiologie, Université Ibrahim Badamasi Babangida, Lapai, Nigéria \\ ²Département de chimie, Université Ibrahim Badamasi Babangida, Lapai, Nigéria \\ *Correspondance à: tovin2009@yahoo.com
}

\section{Abstrait:}

Contexte: La coquille d'œuf, qui est principalement composée de plus de $98 \%$ de cristaux de carbonate de calcium, sert de structure de protection physique et de barrière active du contenu en œufs. Récemment, les propriétés 
antimicrobiennes de la coquille d'œuf sont devenues rapidement un centre d'intérêt parmi les intervenants de l'industrie avicole. Cependant, peu d'études se sont concentrées sur le facteur de rigidité des composants calciques de la coquille d'œuf en tant qu'agent antimicrobien. Ainsi, cette étude a été conçue pour déterminer l'effet de la décalcification sur la capacité de la coquille d'œuf à inhiber les pathogènes bactériens courants de la volaille et des œufs.

Méthodologie: La coquille d'œuf crue dénommée coquille d'œuf calcifiée (CES) et la coquille d'œuf décalcifiée (DES) ont été extraites et transformées en poudre fine. Le protocole standard a été utilisé pour les préparations de CES et DES à des concentrations de $10,5,2,5$ et $1,25 \mathrm{mg} / \mathrm{ml}$, et leurs dosages antibactériens sur des pathogènes bactériens sélectionnés (Bacillus subtilis, Klebsiella pneumoniae, Pseudomonas aeruginosa, Escherichia coli et Salmonella Typhi) ont été réalisés par méthode de diffusion d'agar. Une solution de gentamicine $80 \mathrm{mg}$ (CC1) et de l'eau distillée (CC2) ont servi de témoins. Les données ont été analysées avec SPSS version 20.0 et présentées sous forme de moyenne \pm écart-type pour les statistiques descriptives. Le test bidirectionnel ANOVA de Friedman a été utilisé pour comparer les différences de valeurs moyennes entre CES, DES, CC1 et CC2 au niveau de signification de $p<0,05$. Résultats: Le diamètre moyen de la zone d'inhibition produite par le DES (gamme 13-28 mm) pour les isolats était significativement plus élevé $(p<0,05)$ que celui produit par le CES (gamme $10-21 \mathrm{~mm}$ ). Cependant, le diamètre moyen de la zone d'inhibition produite par CC1 (gentamicine) (gamme 16-40 mm) était plus élevé que celui produit par DES ou CES $(p<0,05)$. Les concentrations de DES et CES n'ont pas d'effet antibactérien significatif sur $B$. subtilis et $K$. pneumoniae $(p>0,05)$, mais ont eu un effet inverse sur $P$. aeruginosa. Dans l'ensemble, le DES avait un meilleur effet inhibiteur que le CES contre $B$. subtilis, $K$. pneumoniae et $P$. aeruginosa, mais notamment, ni le DES ni le CES n'avaient d'effet inhibiteur sur $E$. coli et $S$. Typhi.

Conclusion: Le faible effet antibactérien du CES peut être attribué aux interactions calcium-protéines au sein de la membrane cellulaire bactérienne, ce qui entrave l'absorption ou le mécanisme de mobilité du facteur antibactérien de la coquille d'œuf, mais la décalcification a eu un impact significatif sur le profil antibactérien de la coquille d'œuf pour certaines bactéries isoler. Cependant, S. Typhi et $E$. coli étaient totalement résistants au DES et au CES. Race d'œufs avec une coquille d'œuf calcifiée minimale pour résister à la fragilité du transport, peut améliorer l'indice antibactérien et la durée de conservation des œufs de table.

Mots-clés: décalcification; Antibactérien; Coquille d'oeuf; La volaille; Les agents pathogènes.

\section{Introduction:}

Eggshell matrix is primarily composed of calcium carbonate crystals (98\%) held together by protein and biominerals accounting for the remaining $2 \%$ (1). Rigidity of the eggshell depends on the calcium component that confers active physical barrier against penetration by pathogenic microbes. However, within the average of 30 days shelf-life of table eggs, proteolytic enzymes synthesized by these microbes gradually collapses the eggshell matrix, thereby compromising the active barrier $(2,3,4)$. Bacteria penetration and egg deterioration rates directly correlate with eggshell thickness (5). Perhaps, this indicates, directly or indirectly, that antimicrobial property of eggshell is a function of calcium. Exclusive from the seeming antimicrobial influence of calcium components of eggshell, recent studies have shown that calcium component of eggshell can be an economic alternative to lime as soil stabilizer (6), and can be a combined nutritional therapy for patients with osteoporosis without significantly increasing the level calcium in blood (4).

Antimicrobial properties of eggshell are not prominent but there are prospects on the rigidity factor of calcium components of eggshell as antimicrobial agent. Atee et al., (7) successfully reduced the growth rate of Agrobacterium tumefaciens by $7-10 \%$ and completely inhibited growth using calcium carbonate and nanocalcium carbonate respectively. The increasing prevalence of some of these pathogens and their biotoxins are posing serious threat to the egg industry $(2,8)$. Enterotoxins from E. coli, Salmonella spp, Shigella spp, Campylobacter spp, Listeria monocytogenes and carcinogenic biotoxins from Aspergillus flavus and Aspergillus parasitiscus are among the threats to the global market of poultry and egg industry $(2,5,9)$. Unfortunately, effective management of these pathogens are hampered by antibiotics resistance hype and consequences of antibiotics use/ misuse in poultry industry (10). These have necessitated the search for alternative antimicrobial approaches. Thus, this study aims to assess the impact of calcium component on the antimicrobial properties of eggshell.

\section{Materials and method:}

\section{Collection of eggshells}

Eggshells used for this study were from local chicken breed of Fulani ecotype. The local chickens were fed with household wastes, supplemented with worms and insects in a semiintensive management system.

\section{Preparation of calcified eggshell (CES)}

Five fresh table eggs were cleansed with sterile cotton wool soaked in $70 \%$ alcohol. The posterior ends of the eggs were cracked to allow complete drainage of the egg contents, leaving behind the eggshell and shell membrane which were air-dried at room temperature. The egg- 
shells with membrane were crushed with mortal, pestle into fine powder, and labelled as calcified eggshell (CES). About $1 \mathrm{~g}$ of CES was added into test tube containing $9 \mathrm{ml}$ of distilled water and labelled $100 \mathrm{mg} / \mathrm{ml}$. This was vigorously agitated for about 2-3mins and used as stock solution for preparation of $10 \mathrm{mg} / \mathrm{ml}, 5 \mathrm{mg} / \mathrm{ml}, 2.5 \mathrm{mg} / \mathrm{ml}$ and $1.25 \mathrm{mg} / \mathrm{ml}$ concentrations using distilled water as diluent.

\section{Preparation of decalcified eggshell (DES)}

The theory of decalcifying an egg is based on acid-base reaction. Vinegar (acetic acid) react with calcium carbonate crystal (base) to release carbon dioxide (gas) and calcium residues. Five fresh table eggs were immersed separately into $250 \mathrm{ml}$ beakers containing acetic acid and kept standing for 24 hours for the gas bubbles to escape. Clean spoons were to use to scoop the eggs into fresh $250 \mathrm{ml}$ beakers containing acetic acid and kept for another 24 hrs. After this, the eggs were rinsed in distilled water. The eggs appeared cooked and the inner eggshell of the decalcified eggs were carefully extracted and allowed to dry at room temperature. The extracts were crushed with mortar and pestle into fine powder and labelled as decalcified eggshell (DES). About $1 \mathrm{~g}$ of DES was added into test tube containing $9 \mathrm{ml}$ of distilled water and labelled $100 \mathrm{mg} / \mathrm{ml}$. This was vigorously agitated for about 2-3 mins and used as stock solution for preparation of $10 \mathrm{mg} / \mathrm{ml}, 5 \mathrm{mg} /$ $\mathrm{ml}, 2.5 \mathrm{mg} / \mathrm{ml}$ and $1.25 \mathrm{mg} / \mathrm{ml}$ concentrations using distilled water as diluent.

\section{Preparation of gentamicin control (CC1)}

One milliliter of commercial gentamicin ( $80 \mathrm{mg} / \mathrm{mL})$ solution was added to $7 \mathrm{ml}$ of distilled water to obtain stock solution of $10 \mathrm{mg} / \mathrm{ml}$, which was serially diluted with distilled water to prepare $5 \mathrm{mg} / \mathrm{ml}, 2.5 \mathrm{mg} / \mathrm{ml}$ and $1.25 \mathrm{mg} / \mathrm{ml}$ solutions.

\footnotetext{
Antibacterial activity of test and control samples The antibacterial activities of DES, CES, CC1 (gentamicin positive control) and CC2 (distilled water negative control) were evaluated against Pseudomonas aeruginosa, Salmonella Typhi, Escherichia coli, Klebsiella pneumoniae, and Bacillus subtilis using agar diffusion technique. The microbial strains were obtained from the Bacterial Bank of the Department of Microbiology, Ibrahim Badamasi Babangida University, Lapai.

Each test bacterial isolate was preenriched in Mueller-Hinton broth (MHB) for 24 hours at $37^{\circ} \mathrm{C}$ and suspension equivalent to 0.5 McFarland standard solution $\left(10^{8} \mathrm{CFU} / \mathrm{ml}\right)$ was prepared. One $\mathrm{ml}$ of the suspension was inocu-
}

lated onto wells of Mueller-Hinton agar (each for DES, CES, CC1 and CC2) that bad been bored on each plate using a sterile $4 \mathrm{~mm}$ cock-borer. The inoculated plates were incubated aerobically at $37^{\circ} \mathrm{C}$ for $18-24$ hours after which the diameter of zone of inhibition (in $\mathrm{mm}$ ) around each well was measured with a calibrated meter rule. The assay was performed in triplicates, and the mean zone diameters of inhibition produced by the test and control samples was calculated for each bacterial isolate.

\section{Statistical analysis}

Statistical analysis was performed using SPSS software version 20.0. Data were presented as mean \pm standard deviation and Friedman's two-way test ANOVA was used to compare the difference between the mean zone diameter of inhibition produced by DES, CES and CC1. $P$ value less than 0.05 was considered statistically significant.

\section{Results:}

Bacillus subtilis was relatively inhibited at all the concentrations of DES and CES with mean zone diameters of inhibition ranging from $15 \pm 2.38 \mathrm{~mm}$ to $24 \pm 4.20 \mathrm{~mm}$. Comparably, the mean zone diameters of inhibition of this bacterium to DES and CES were not significantly different $(p>0.05)$ but were significantly $(p<0.05)$ lower than that for gentamicin control (Fig 1 ).

The zone diameters of inhibition by DES and CES for $P$. aeruginosa were trendy but did not correlate with the different concentrations of DES and CES. The mean zone diameters of inhibition were significantly different $(p<0.05)$ between DES (25-28 $1.29 \mathrm{~mm})$ and CES (17-21 $\pm 1.70 \mathrm{~mm}$ ) and from the gentamicin control (28$34 \pm 2.65 \mathrm{~mm}$ ) (Fig 2).

Similarly, K. pneumoniae showed trendy inhibition zone diameters to DES and CES. The mean zone diameters of inhibition of DES (13$15 \pm 0.96 \mathrm{~mm})$ and CES $(10-15 \pm 2.65 \mathrm{~mm})$ were only significantly different $(p<0.05)$ at $2.5 \mathrm{mg} / \mathrm{I}$ while all other test concentrations $(10 \mathrm{mg} / \mathrm{l}, 5$ $\mathrm{mg} / \mathrm{l}$ and $1.25 \mathrm{mg} / \mathrm{l}$ ) did not show significant difference $(p>0.05)$. However, the mean zone diameter of inhibition to the gentamicin control sample $(16-27 \pm 4.65 \mathrm{~mm})$ was significantly different $(p<0.05)$ compared to the DES and CES test samples (Fig 3).

The DES and CES had no effect on $S$. Typhi and $E$. coli, as no zones of inhibition were produced. Expectedly, the concentrations of the gentamicin control sample were inversely proportional to the mean zone diameters of inhibition (Figs 4 and 5). 


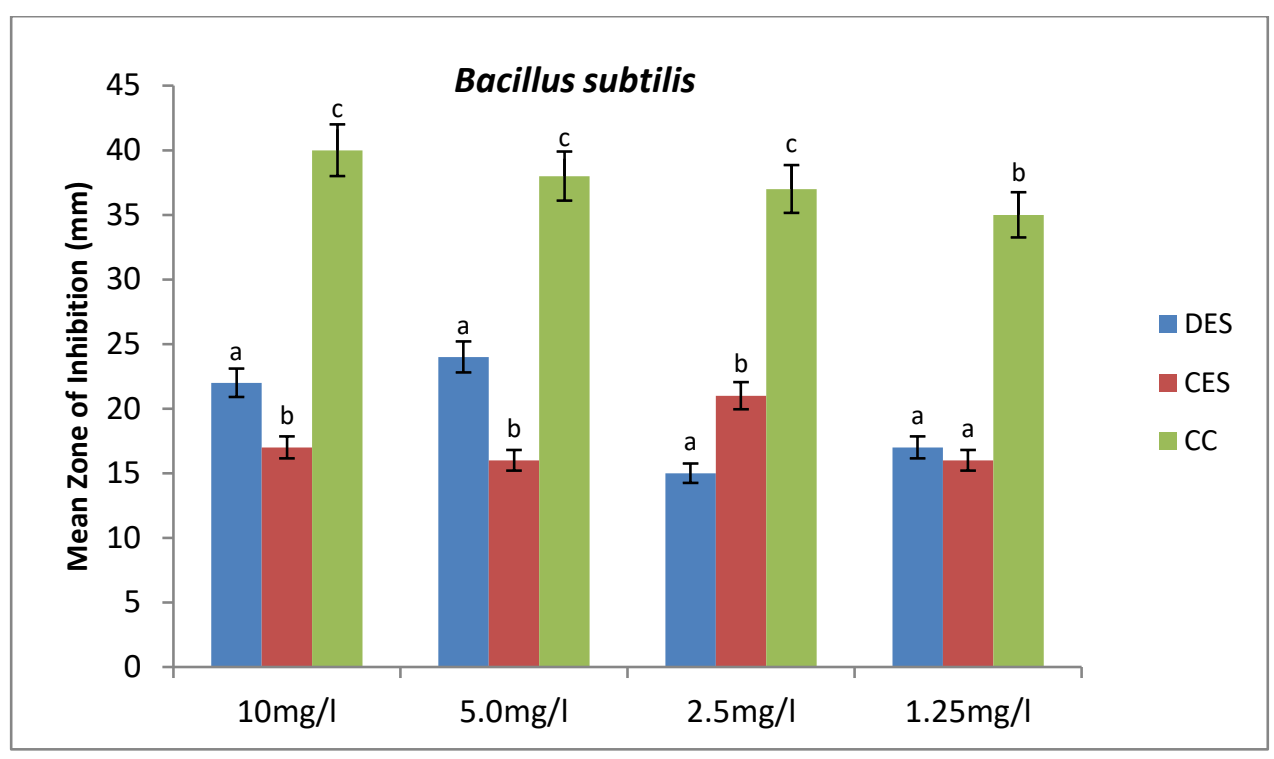

Fig. 1: Susceptibility profile of Bacillus subtilis to DES and CES

DES = Decalcified Eggshell; CES = Calcium containing Eggshell; CC = Control Gentamicin $(80 \mathrm{mg} / \mathrm{ml})$; *Bars bearing different alphabets are significantly different $(p<0.05)$ across each concentration subsets ; $* * \ddagger=$ Standard deviation $( \pm)$ of the zones of inhibitions values

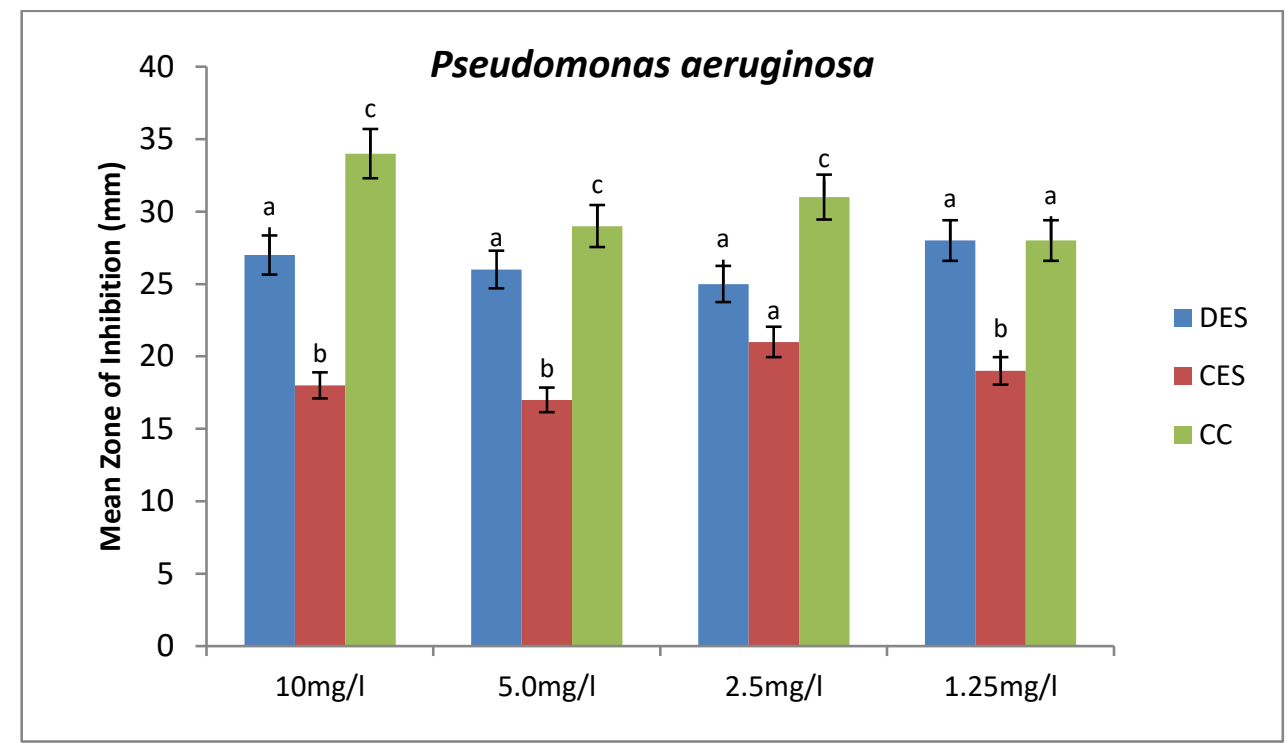

Fig. 2: Susceptibility profile of Pseudomonas aeruginosa to DES and CES

DES = Decalcified Eggshell; CES = Calcium containing Eggshell; CC = Control Gentamicin $(80 \mathrm{mg} / \mathrm{ml}) ;$ *Bars bearing different alphabets are significantly different $(p<0.05)$ across each concentration subsets $* * \neq=$ Standard deviation $( \pm)$ of the zones of inhibitions values 


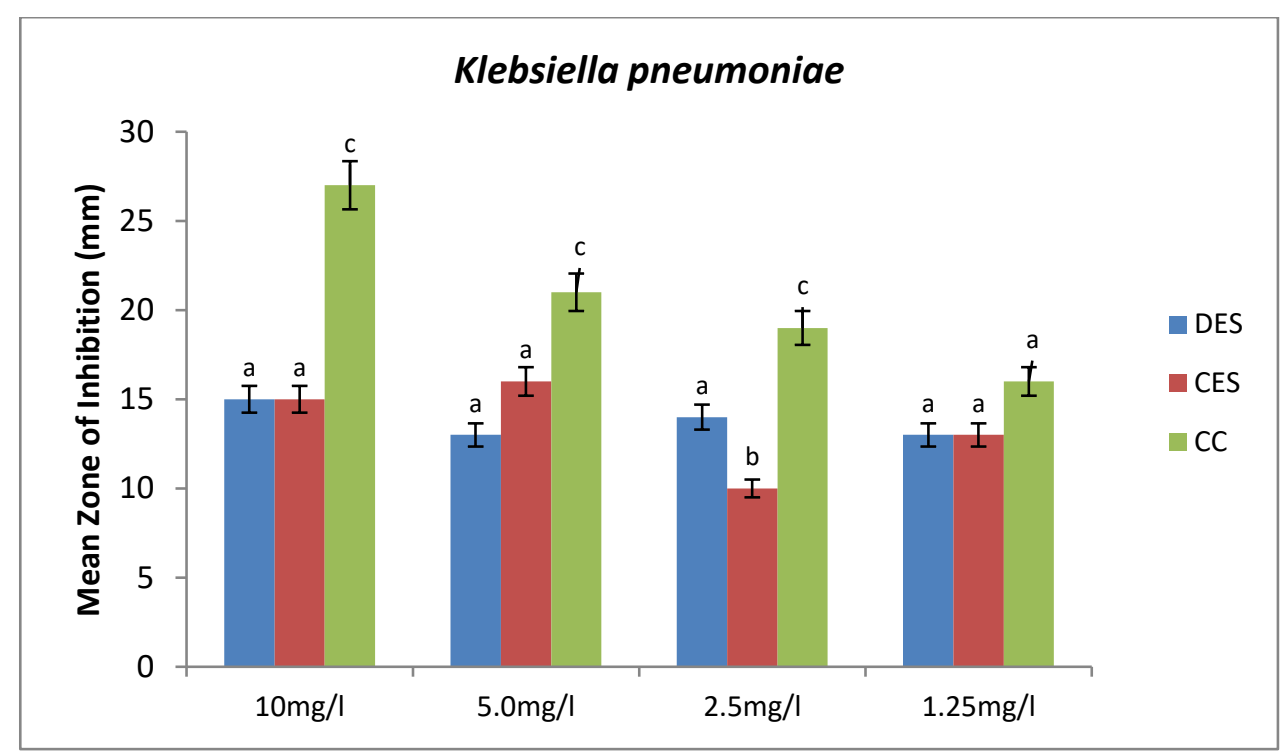

Fig. 3: Susceptibility profile of Klebsiella pneumoniae to DES and CES

DES = Decalcified Eggshell; CES = Calcium containing Eggshell; CC = Control Gentamicin $(80 \mathrm{mg} / \mathrm{ml})$ *Bars bearing different alphabets are significantly different $(p<0.05)$ across each concentration subsets $* * \neq=$ Standard deviation $( \pm)$ of the zones of inhibitions values

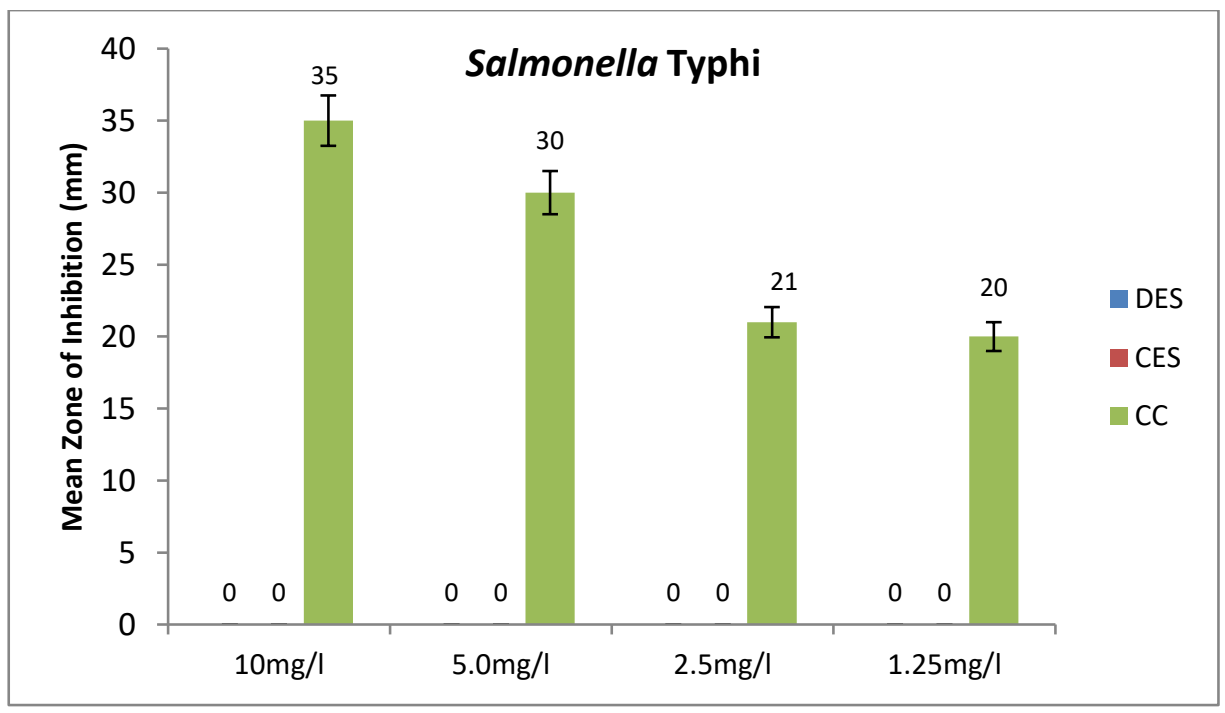

Fig. 4: Susceptibility profile of Salmonella Typhi to DES and CES

DES = Decalcified Eggshell; CES = Calcium containing Eggshell $; C C=$ Control Gentamicin $(80 \mathrm{mg} / \mathrm{ml})$ *Bars bearing different alphabets are significantly different $(p<0.05)$ across each concentration subsets $* * \neq=$ Standard deviation $( \pm)$ of the zones of inhibitions values 


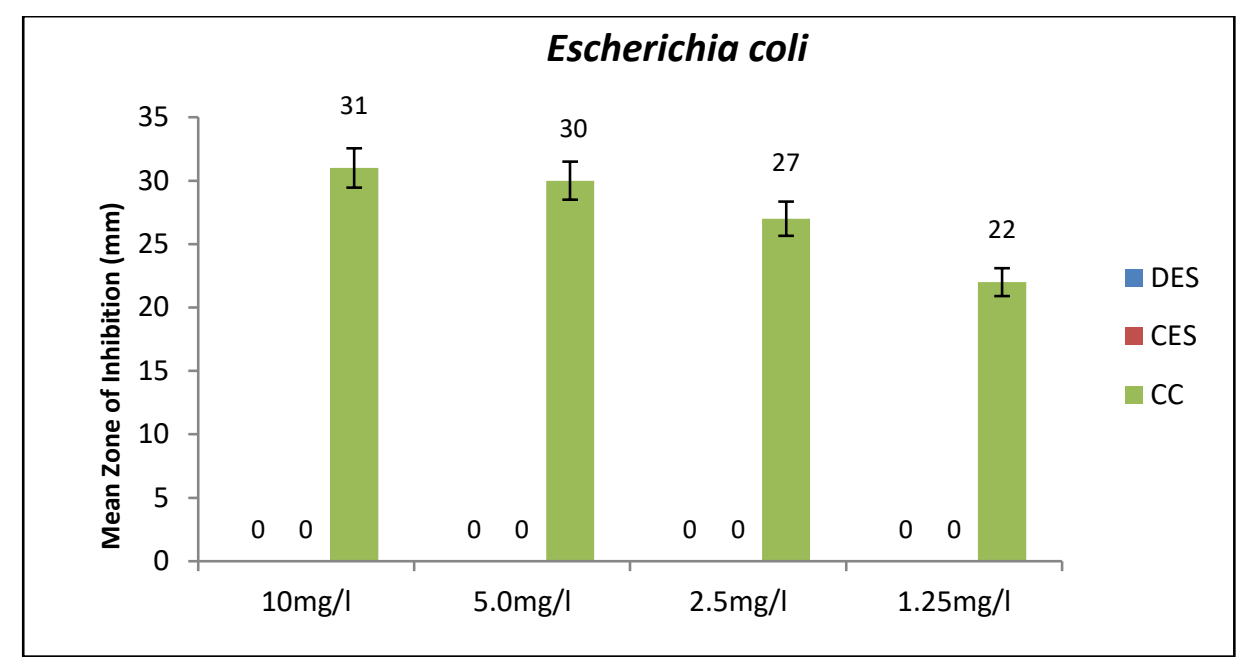

Fig. 5: Susceptibility profile of Escherichia coli to DES and CES

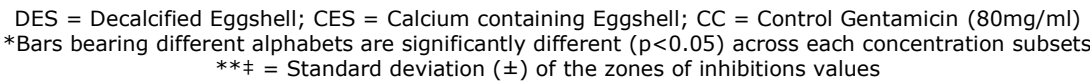

\section{Discussion}

Susceptibility of $B$. subtilis and $P$. aeruginosa to purified protein extracts (ansocalcin and ovocleidin-17) of eggshell (11) have been documented, where the authors reported that calcium enhances antibacterial activity, but this is contrary to the findings of our study. Perhaps, extraction and purified nature of these eggshell proteins require calcium binding to be effective unlike the whole eggshell used in our study. Klebsiella spp as opportunistic pathogens are common isolates of poultry products with relative average resistance rate of $50-60 \%$ to the common antimicrobial drugs $(12,13)$. Based on the efficiency of eggshells to inhibit this opportunistic pathogen, proper hygiene is advocated to avoid compromising the integrity of eggshells during handling and processing.

Total resistance of S. Typhi to DES and CES was not a surprising observation in our study as several reports spanning decades have implicated Salmonella as an infamous poultry product contaminant (14), agent of disease outbreaks (15), and significant economic losses (9). Perhaps, the ability of Salmonella to infect eggs prior to shell formation enables it to avert most antimicrobial agents popularly used within the poultry industry, as shown by $S$. Typhi and $E$. coli total resistant to all concentrations of DES and CES in our study. Similarly, more than $95 \%$ trans shell penetrative ability of $E$. coli was observed by Cook et al., (8), which connotes a strong resistance of $E$. coli to antibacterial factor of eggshells. The authors also concluded that bacterial trans-shell invasions were not proportional to the thickness of eggshell, which supports the inference of our study that calcium (thickness factor of eggshells) is not a determinant factor of antimicrobial activity of eggshell.

Although high calcium content indicates superior protective structural and physical strength of eggshell, it significantly decreases the antibacterial profiles of eggshell. The absorption or mobility mechanism of antimicrobial factor of eggshell may be limited by calcium-protein interactions within bacterial cell membrane. This may explain why eggs with less calcium content in shell have extended shelf-life compared to those with higher calcium content (16). Comparative variations of calcium content of eggshell (17) is known to add more validity to notable shelf-life differences of eggs.

\section{Conclusion:}

The poor antibacterial effects of CES in our study may be attributed to the calciumprotein interactions within bacterial cell membrane, which hinders absorption or mobility mechanism of antibacterial factor of the eggshell. Decalcification have significant positive impact on the antibacterial profile of eggshell. However, $S$. Typhi and $E$. coli were totally resistant to both DES and CES. Thus, this study opined that combination of proper hygiene and special breed of eggs with moderate calcified eggshell (to withstand transportation fragility) will enhance microbial shelf-life of table eggs. 


\section{References:}

1. Mann, K., and Mann, M. The proteome of calcified layer organic matrix of turkey (Meleagris gallopavo) eggshell. Proteome Science Biomedical Central. 2013; 11 (40): 1-15.

2. Salem, R. M., El-Kaseh, R. M., and El-Diasty, E. M. A Study on the fungal contamination and prevalence of Aflatoxins and some antibiotic residues in table eggs. 2008. Arab J. Biotech., 12: 65-72.

3. Shwetha, A., Dhananjaya, S. K., Ananda, S. M. Comparative study on calcium content in egg shells of different birds. Int J Zool. Studies. 2018; 3 (4): 31-33.

4. King'ori, A. M. A review of the uses of poultry eggshells and shell membrane. Int J Poultry Sci. 2011; 10 (11): 908-912.

5. Chen, X., Li, X., He, Z., et al. Comparative study of eggshell antibacterial effectivity in precocial and altricial birds using Escherichia coli. PLoS One. 2019; 14 (7): e0220054

https://doi.org/10.1371/journal.pone.0220054

6. Amu, O. O., Fajobi, A. B., and Oke, B. O. Effect of eggshell powder on the stabilization potential of lime on an expansive clay soil. Resource. J Agric Biol Sci. 2005; 1 : 80-84.

7. Ataee, R. A., Derakhshanpour, J., Mehrabi-Tavana, A., and Eydi, A. Antibacterial effect of calcium carbonate nanoparticles on Agrobacterium tumefaciens. Iranian Journal of Military Medicine. $2011 ; 13$ (2): 65 - 70.

8. Cook, M. I., Beissinger, S. R., Toranzos, G. A., and Arendt, W. J. Microbial infection affects egg viability and incubation behavior in a tropical passerine. Behavioral Ecology. 2005; 16: 30-36.

9. Kristine, P. 200 million eggs recalled after nearly two dozen were sickened with salmonella, officials say. The Washington Post. 2018. Available from: https://www.washingtonpost.com/news/business/ wp/2018/04/15/200-million-eggs-recalled-after- nearly-two-dozen-were-sickened-with-salmonellaofficials-say/?utm_term=.e3f8c19f3207.

10. Balogu, T. V., Nwaugo, V. O., Onyeagba, R. A., and Balogu, D. O. Assessment of Listeria monocytogenes and biofilm formation in poultry abattoirs. Develop J Sci Technol Res. 2013; 2 (1): 165-171

11. Wellman-Labadiea, O., Lakshminarayananb, R., and Hincke, M. T. Antimicrobial properties of avian eggshell-specific C-type lectin-like proteins. FEBS Letters. 2008; 582 (5): 699-704.

https://doi.org/10.1016/j.febslet.2008.01.043.

12. Fielding, B. C., Mnabisa, A., Gouws, P. A., and Morris, T. Antimicrobial-resistant Klebsiella species isolated from free-range chicken samples in an informal settlement. Archives of Medical Science 2012; 8 (1): 39-42.

https://doi.org/10.5114/aoms.2012.27278

13. Ramaswamy, V., Saravanabava, K., Latha, N., Nachimuthu, K., Manickam, M. Staphylococcus and Klebsiella infection in layer chickens. Indian Journal of Poultry Science. 1997; 32 (3): 308-310

14. Long, M., Yu, H., Chen, L. et al. Recovery of Salmonella isolated from eggs and the commercial layer farms. Gut Pathogens 2017; 9: 74

https://doi.org/10.1186/s13099-017-0223-8.

15. CDC. Salmonella and Eggs. National Center for Emerging and Zoonotic Infectious Diseases, Division of Foodborne, Waterborne, and Environmental Diseases, 2020.

https://www.cdc.gov/features/salmonellaeggs/index.html. Cook, M. I., Beissinger, S. R., Toranzos, G. A., Rodriguez, R. A., and Arendt, W. J. Trans-shell infection by pathogenic micro-organisms reduces the shelf life of non-incubated bird's eggs: a constraint on the onset of incubation? Proceedings of the Royal Society of London, Series B. 2003; 270: 2233-2240.

17. Adeyeye, E. I. Comparative study on the characteristics of Egg Shells of some bird species. Bull Chem Soc Ethiop. 2009; 23 (2): 159-166. 